Abel was the recipient of many academic honours and became honorary or foreign member of many learned societies in many countries. Perhaps none would have given him greater pleasure and satisfaction than his election as foreign member of the Royal Society, which took place only a few days before his death.

During the time in which pharmacology has been emerging as a separate science with its own laboratories and followers, Abel has been an outstanding personality to whom that science must for ever remain in debt. His tall spare figure and genial presence will be sadly missed not only in his own country but also wherever men forgather who are interested in the progress of medical research. J. A. GUNN.

\section{Sir Colin Mackenzie}

WE regret to announce the death of Sir Colin Mackenzie, formerly director of the Australian Institute of Anatomy, at the age of sixty-one years.

Though Sir Colin gained great distinction as an orthopædic surgeon yet he devoted himself to anatomy with an enthusiasm that might be expected to flow only from great genius. He was lecturer and examiner in anatomy in the University of Melbourne. He was a member of the Anatomical Society, served eagerly the Zoological Society of his city, established and furnished a whole museum with dissections of marsupials, strove to secure the preservation of the Australian fauna, and wrote their comparative anatomy in four volumes. His faith in anatomy induced the Commonwealth Government to erect in its Federal capital an anatomical institute under his direction.

Sir Colin's book, "The Action of Muscles", contains an epitome of his anatomical observations and ideas. In about fifty pages, under the title of principles, he states what he has come to believe about muscles. The reader is constantly referred to what happens in the wombat, frequently assured that the action of muscles can only be understood by an appeal to their evolutionary history, and is admonished to consider the behaviour of the primates and the assumption of the erect posture. The principles which he enunciates owe nothing to these allusions to the primates or to the illustrations of marsupial anatomy. The dissections of the wombat seem quite irrelevant to his principles of muscle action which have to do with the treatment of paralysis.

More than thirty years ago, when the treatment of fractures and muscular palsies was very bad, Mackenzie was preaching and practising his principles. He pointed out the error of describing a muscle as paralysed because it was unable to perform its maximum amount of work. More careful inquiry might discover that such a muscle still had some power. The muscles of the shoulder might not be able to lift the limb against gravity, yet perhaps could swing the arm from the side when the body was horizontal and gravity thus excluded. Inflamed nerve cells like any other inflamed tissue must be put at rest. A motor nerve cell could only be rested through its muscle. A muscle is placed in a state of physiological rest when its antagonists are kept over- stretched. Thus by rest, and then utilizing the residual power left in an affected muscle, by patience and persistence he accomplished much. Muscle and tendon transplants were advised only when reeducation seemed hopeful. He cut through much that was unimportant in the teaching of muscle action by his blunt insistence that a muscle had always one prime action to perform and only cooperated fully in other actions after its prime action had been fulfilled. He insisted upon muscle reeducation and saw that this was only hopeful when the alteration of the attachments demanded the least change in function and when there was greatest cerebral control. Thus the gain in usefulness was in general far greater in the arm than in the leg.

His work in mitigating the terrible consequences of infantile palsy led to far greater interest in these matters. His experience was made available in the orthopædic hospitals of Great Britain during and after the Great War. In his own city more people skilful in these matters are available than perhaps anywhere else. $\mathrm{He}$ deserves an honourable place amongst "The Menders of the Maimed".

\section{Miss D. M. Liddell}

WE regret to record the death, which took place on May 25 at the Old Rectory, Stratfield Turgis, Basingstoke, of Miss Dorothy Mary Liddell, well known as an experienced and fortunate excavator on archæological sites.

Much of Miss Liddell's early experience and train. ing in archæological work was gained by her participation in the excavation of the famous Windmill Hill site of neolithic culture, explored by Mr. Alexander Keiller. The effect of this training, combined with a natural flair for archæological work, were used to full advantage in her discovery and patient exploration of the Roman house at Lodge Farm, North Warnborough, and also in the discovery and examination under the auspices of the Hampshire Field Club of the extensive pit-dwellings at Chosely Farm, Odiham. Previously she had spent some seasons at work on Chilworth Ring, on Meon Hill. Her most lasting contribution to archæological analysis, however, is probably the patient and detailed study she made of stamped impressions on neolithic pottery. The results of prolonged examina. tion of innumerable specimens of potsherds and of a prolonged series of experiments and photographic work were embodied in an article in Antiquity in 1929, "New Light on an Old Problem", in which the central idea of the use of bird bones as an instrument of ornamentation had been suggested to her by the discovery of a large quantity of "West Kennet" pottery associated with a small bird bone.

WE regret to announce the following deaths :

Prof. E. W. Brown, F.R.S., emeritus professor of mathematics in Yale University, an authority on lunar theory, aged seventy-one years.

Mr. G. Nevill Huntly, consulting chemist, on August 2, aged seventy-one years. 